\title{
Forage Yield of Japanese Honeysuckle after Repeated Burning or Mowing
}

\author{
JOHN J. STRANSKY
}

\section{Abstract}

Japanese honeysuckle (Lonicera japonica) plantings were burned, mowed, or left untreated in February 1973, and again in March 1978, to measure forage yields from honeysuckle after repeated treatments and to determine whether burning or mowing confines honeysuckle to food plots and prevents accumulation of large, impenetrable mats. Two growing seasons after the 1st treatment, total honeysuckle yield ( $\mathrm{kg} / \mathrm{ha}$ ) was greatest on controls and least on burned plots. One and two growing seasons after the 2 nd treatment, yield on the mowed plots was significantly greater than that on the control or burned plots. However, honeysuckle formed large, solid mats on control and mowed plots due to the numerous, intertwined runners, while burning reduced the dense growth between plants making them accessible to white-tailed deer (Odocoileus virginianus).

Japanese honeysuckle is a woody vine that often is planted on wildlife food plots in the southern United States. Its easily digestible and nutritious browse is available during the critical late fall and winter months when other browse is scarce (Segelquist et al. 1971, 1975). However, honeysuckle forms large, solid mats with only the perimeter remaining available to white-tailed deer. Also, when honeysuckle escapes from the food plots, its climbing habit reduces the growth of young trees in adjacent forest regeneration areas. The objectives of this study were to: (1) measure forage yields from honeysuckle after repeated burning or mowing and (2) determine whether burning or mowing prevents accumulation of large, impenetrable mats.

\section{Study Area and Methods}

Honeysuckle was planted in an open field on the Stephen F. Austin Experimental Forest near Nacogdoches, Texas. Soils were of the Besner (coarse-loamy, siliceous, thermic, glossic paleudalf) and Attoyac (fine-loamy, siliceous, thermic, typic paleudalf) series, which are well drained upland soils (Dolezel 1980). The area had once been in agricultural cultivation and subsequently was grazed by cattle until the mid-1950's.

Honeysuckle cuttings were rooted in greenhouse flats in May 1967. In February 1970, 400 rooted cuttings were planted in the plowed and disked field at about $3 \times 3 \mathrm{~m}$ spacing in 20 rows. One week after planting, ammonium nitrate was spread uniformly over the entire area at the rate of $300 \mathrm{~kg} / \mathrm{ha}$. Initial survival was near $100 \%$. Weeds around the young plants were kept down by hoeing and cultivation during the 1 st and 2 nd growing seasons. Three years after transplanting, the honeysuckle plants were about $30 \mathrm{~cm}$ high. Common associated plants were blackberry (Rubus spp.), broomsedge (Adropogon spp.), panicum grasses ( Panicum spp.), ragweeds (Ambrosia spp.), and occasional sprouts of sassafras (Sassafras albidum), oaks (Quercus spp.), and persimmon (Diospyros virginiana).

A simple randomized block design consisting of 3 treatments in 3 blocks was used. In February 1973, the following treatments were

\footnotetext{
Author is research forester, USDA Forest Service, Wildlife Habitat and Silviculture Laboratory, Nacogdoches, Texas 75962 . Laboratory is maintained in cooperation with the School of Forestry, Stephen F. Austin State University.

Thanks are extended to D.D. Devet, L.K. Halls, D.W. Lay, and C.A. Segelquist for reviewing drafts of the manuscript.

Manuscript received March 7, 1983.
}

applied to $20 \times 20 \mathrm{~m}$ plots, each containing 36 honeysuckle plants: (1) burning with a headfire, (2) mowing with a rotary mower $5 \mathrm{~cm}$ above the ground, and (3) not treated (control). In March 1978, the treatments were repeated on the same plots.

In November 1974, 2 growing seasons after burning and mowing, the current season's growth was clipped for yield determinations from within a $1.01-\mathrm{m}^{2}(1 / 4$ milacre $)$ steelwire frame centered around each of 8 randomly sampled plants per plot. The same technique was used for measuring yield of the runners between plants by placing the frame mid way between adjacent plants. Sampling was repeated in November 1978, one growing season after the 2nd treatment, and again in October 1979, 2 growing seasons after the 2nd treatment.

The yield samples, oven-dried to constant weight at $65^{\circ} \mathrm{C}$, were separated into leaves and stems. Differences in mean yields among treatments and between plants and runners were tested within years by analyses of variance and by Duncan's new multiple range test $(\alpha=0.05)$.

\section{Results and Discussion}

Control plots had dense, solid honeysuckle mats, ranging in height from 30 to $150 \mathrm{~cm}$. In November 1974, yield of the new growth from the original plants was significantly greater than that growing on the interval midway between the plants. Significant differences did not occur in November 1978, nor in October 1979 (Table 1). These and other treatment yields are in agreement with

Table 1. Average dry-matter yield (kg/ha) of honeysuckle plants and runners between plants by treatment and date $(N=8$ for plants and runners; $N=16$ for $\overline{\mathbf{X}}$ ). 1

\begin{tabular}{lccc}
\hline \hline & \multicolumn{3}{c}{ Dry-matter yield } \\
\cline { 2 - 4 } Treatment & Plants & Runners & $\bar{X}$ \\
\hline & & November 1974 \\
Control & $3,802 \mathrm{a}$ & $2,315 \mathrm{bc}$ & $3,058 \mathrm{~d}^{2}$ \\
Burning & $2,279 \mathrm{bc}$ & $1,272 \mathrm{~b}$ & $1,775 \mathrm{e}$ \\
Mowing & $2,996 \mathrm{a}$ & $2,012 \mathrm{bc}$ & $2,504 \mathrm{de}$ \\
& & & \\
& & November 1978 & \\
Control & $2,329 \mathrm{ab}$ & $2,214 \mathrm{ab}$ & $2,271 \mathrm{~d}$ \\
Burning & $2,435 \mathrm{ab}$ & $1,727 \mathrm{~b}$ & $2,081 \mathrm{~d}$ \\
Mowing & $2,982 \mathrm{a}$ & $2,889 \mathrm{a}$ & $2,935 \mathrm{e}$ \\
& & & \\
Control & $2,170 \mathrm{~b}$ & October 1979 & $2,458 \mathrm{~d}$ \\
Burning & $2,509 \mathrm{ab}$ & $1,600 \mathrm{~b}$ & $2,054 \mathrm{~d}$ \\
Mowing & $3,715 \mathrm{a}$ & $3,818 \mathrm{a}$ & $3,766 \mathrm{e}$ \\
\hline
\end{tabular}

Treatments applied in February 1973 and March 1978.

2 Yields of plant and runners within a yearly group that are not followed by a common letter are statistically different $(P \leq 0.05)$ reading both horizontally and vertically. Significance indicator letters of $\bar{X}$ column read vertically.

data on honeysuckle growth from Arkansas (Segelquist et al. 1975, Dickson et al. 1978).

On mowed plots, except in 1974 , no significant differences occurred between the yields of the plants and the runners (Table 1). 
Two months after the 1st treatment, the plots were uniformly and densely covered by honeysuckle. The original plants and the severed runners, occupying the intervals between plants, sprouted where cut by the mower and created the impression of a sheared lawn about $20 \mathrm{~cm}$ tall. In November 1974, the mowed plots had the same uniform appearance, but the cover's depth increased to about $60 \mathrm{~cm}$. Few hardwood sprouts extended above the honeysuckle mat. After the 2nd treatment, mowing consistently resulted in an even distribution of honeysuckle over the entire plot. Mowing did not prevent honeysuckle from forming dense mats because growth on the runners was nearly the same as that on the plants in 1978 and 1979, 1 and 2 growing seasons after the 2 nd treatment. At the same time the mean total yield of mowed plots exceeded that of the controls by $23 \%$ and $35 \%$ respectively.

On burned plots, none of the original plants were killed by the fire, but it consumed all their above-ground portions, including the runners extending into the interval between plants. One year after burning, the original plants were still discernible, and runners between plants were few. At no time was there a statistically significant difference between the total yield of the burned plants and the runners, although the original plants consistently yielded more forage than the runners.

In the fall of 1978 and 1979, the growth of runners in burned plots was significantly less than that of runners in the mowed plots. There was no statistically significant difference between the yield of burned plants of runners, and of the control plants and runners, except in 1974, when the yield of burned plots was reduced. Nevertheless, the burned plots were more accessible to deer because growth of the runners was consistently less on burns than on the controls. Runners on burned plots were less likely to spread into adjacent areas than were those on the mowed or the control plots.

In November 1978 and October 1979, after the 2nd treatment, mean total yields of both plants and runners on burned and control areas were significantly less than that of the mowed plots (Table 1). The ratio of stems to leaves did not differ significantly among treatments during any year.

Leaf analyses in 1973 showed that crude protein was highest on the burned plots, but that neither calcium nor phosphorus was affected significantly by treatments (Stransky et al. 1975). Burning appears to be a useful and inexpensive way to confine honeysuckle to foodplots and provide large amounts of nutritious plants to white-tailed deer.

\section{Literature Cited}

Dickson, J.G., C.A. Segelquist, and M.J. Rogers. 1978. Establishment of Japanese honeysuckle in the Ozark Mountains. Proc. Ann. Conf. S.E. Ass. Fish and Wildl. Agencies 32:242-245.

Dolezel, R. 1980. Soil survey of Nacodgdoches County, Texas. U.S. Gov. Printing Office, Washington, DC. 146 p. and 53 maps.

Segelquist, C.A., M. Rogers, and F.D. Ward. 1971. Quantity and quality of Japanese honeysuckle on Arkansas Ozark food plots. Proc. Ann. Conf. S.E. Ass. Game and Fish Commissioners 25:47-53.

Segelquist, C.A., M. Rogers, and F.D. Ward. 1975. Response of Japanese honeysuckle to management in the Arkansas Ozarks. Proc. Ann. Conf. S.E. Ass. Game and Fish Commissioners 29:370-373.

Stransky, J.J., J.N. Hale, and L.K. Halls. 1975. Nutrient content and yield of burned or mowed Japanese honeysuckle. Proc. Ann. Conf. S.E. Ass. Game and Fish Commissioners 29:403-406.

CHANGE OF ADDRESS notices should be sent to the Managing Editor, 2760 West Fifth Ave., Denver, Colo. 80204, no later than the first day of the month of issue. Copies lost due to change of address cannot be replaced unless adequate notice is given. To assure uninterrupted service, provide your local postmaster with a Change of Address Order (POD Form 3575) indicating thereon to guarantee forwarding postage for second-class mail. 